\title{
Formononetin could increase soluble-APP $\alpha$ secretion by up-regulating ADAM10 level
}

\author{
Ting Zhou, Miao Shun, Liang Zhou, Huan Yang, Kaiyin Zhong, Ximeng Zhang, Hui Zhang, Dongsheng Fan,
} Dehua Chui ${ }^{*}$

From 2011 International Conference on Molecular Neurodegeneration

Shanghai, China. 22-24 September 2011

\section{Background}

Formononetin, which is used as neuroprotective medicine, was reported to have benefits for Alzheimer's disease (AD). However, little is known on how Formononetin exerts these beneficial effects. In this study, we investigated the molecular mechanisms through which Formononetin increased soluble-APP $\alpha(\mathrm{sAPP} \alpha)$ secretion and thus was neuroprotective in human-APP Swedish mutation cell cultures (N2a-APP cell).

\section{Method and results}

By using N2a-APP cell cultures combined with hypoxia treatment, we confirmed that chronic treatment with Formononetin could have neuroprotective effects, which was followed by reduced and increased Caspase 3 activity and cell viability. Strikingly, our data revealed that the Caspase3-blocking effect of Formononetin was largely mediated by stimulation of $\alpha$-secretase cleavage of APP, resulting in increased secretion of its soluble form, sAPP $\alpha$. Moreover, the protective effect of Formononetin was totally inhibited by TAPI-2, an $\alpha$-secretase complex inhibitor, suggesting the role of the sAPP $\alpha$ pathway in the neuroprotective response to Formononetin. Furthermore, we also revealed that the stimulation effect of Formononetin on $\alpha$-secretase activity was mainly a result of up-regulating ADAM10 expression at the transcriptional level.

\section{Conclusion}

Altogether, our study provides novel insights into how Formononetin mediated stimulation of the ADAM10sAPP $\alpha$ pathway and resulting neuronal protective effect.

\footnotetext{
* Correspondence: dchui@bjmu.edu.cn

Peking University Neuroscience Research Institute, Dep. of Neurology, Peking University Third Hospital, Beijing 100191, China
}

\begin{abstract}
Acknowledgment
We thank Dr. Sangram S. Sisodia (University of Chicago, Chicago) for providing Mouse N2a neuroblastoma cells stably expressing PS1wt and APPsw. This work was supported by the National Natural Science Foundation of China (NSFC; Grants No.30973145), Doctoral Fund of Ministry of Education (20090001110058) and the National High Technology Research and Development Program of China (973 Program, No. 2012CB911004).
\end{abstract}

Published: 7 February 2012

doi:10.1186/1750-1326-7-S1-O10

Cite this article as: Zhou et al:: Formononetin could increase solubleAPP $\alpha$ secretion by up-regulating ADAM10 level. Molecular

Neurodegeneration 2012 7(Suppl 1):010.
Submit your next manuscript to BioMed Central and take full advantage of:

- Convenient online submission

- Thorough peer review

- No space constraints or color figure charges

- Immediate publication on acceptance

- Inclusion in PubMed, CAS, Scopus and Google Scholar

- Research which is freely available for redistribution

Submit your manuscript at www.biomedcentral.com/submit
() Biomed Central
C Biomed Central

(c) 2012 Zhou et al; licensee BioMed Central Ltd. This is an Open Access article distributed under the terms of the Creative Commons Attribution License (http://creativecommons.org/licenses/by/2.0), which permits unrestricted use, distribution, and reproduction in any medium, provided the original work is properly cited. 